\title{
Evaluation of Grain/Seed Yield and Yield Components of Finger Millet and Three Vetch Species Intercropped at Various Seeding Ratios at Bako, Ethiopia
}

\author{
Wakgari Keba ${ }^{(D},{ }^{1}$ Taye Tolemariam, ${ }^{2}$ and Abdo Mohammed $^{2}$ \\ ${ }^{1}$ Bako Agricultural Research Center, PO Box 03, Bako, Ethiopia \\ ${ }^{2}$ Jimma University, PO Box 378, Jimma, Ethiopia \\ Correspondence should be addressed to Wakgari Keba; wkwakeba@gmail.com
}

Received 28 December 2021; Revised 26 January 2022; Accepted 9 February 2022; Published 27 February 2022

Academic Editor: Shah Fahad

Copyright (C) 2022 Wakgari Keba et al. This is an open access article distributed under the Creative Commons Attribution License, which permits unrestricted use, distribution, and reproduction in any medium, provided the original work is properly cited.

Production of finger millet and vetch species in Ethiopia targets mostly on sole cropping system without considering the relative performance of varieties of varying seeding ratios under finger millet/vetch intercropping. Thus, this study was conducted to evaluate grain yield and yield components of three vetch species and finger millet intercropped at different seeding ratios. Factorial combination of three vetch species and five seeding ratios $(0: 100,25: 75,50: 50,75: 25$, and $100: 0 \%$ finger millet: vetch) were laid out in a randomized complete block design (RCBD) with three replications. Analysis of variance showed that intercropping had a significant $(P<0.05)$ effect on plant height, heads per plant, fingers per head, and grain yield of finger millet. The highest grain yield $\left(2058.75 \mathrm{~kg} \mathrm{ha}^{-1}\right)$ of finger millet was harvested from a treatment combination of $75 \%$ finger millet $+25 \%$ Vicia villosa. Analysis of variance also showed that plant height, leaves per plant, branches per plant, pods per plant, seeds per pod, and seed yield of vetch species had significantly varied $(P<0.05)$ for the tested treatments. Maximum and minimum seed yields $(236.19$ and $106.45 \mathrm{~kg} \mathrm{ha}^{-1}$ ) of vetch were harvested from $25 \%$ finger millet $+75 \%$ Vicia sativa and $75 \%$ finger millet $+25 \%$ Vicia villosa, respectively. LER and RCC were improved due to intercropping different species of vetch with finger millet at various seeding ratios. The highest total LER (1.146) and RCC (3.00) were obtained from $75 \%$ finger millet $+25 \%$ Vicia villosa. Thus, it can be concluded that in Bako and similar agroecologies, where feed shortage is a critical problem, intercropping of $75 \%$ finger millet $+25 \%$ Vicia villosa can be used to alleviate the existing feed shortage in smallholder farming system.

\section{Introduction}

In the developing countries of the world, both human and livestock populations increase side by side from time to time, despite the limited resources that the two entities can absorb [1]. Crop diversification through intercropping has been shown to improve crop productivity and profitability, conserve resources, and provide a form of biological insurance against risk and abnormal rainfall patterns in dry land environments [2]. Intercropping can be defined as growing two or more crops in the same area of land. The main goal of intercropping is to get a higher yield on a given piece of land by better utilizing growth resources that would otherwise not be utilized by a single crop [3]. In addition, it is important for the development of sustainable food production systems, especially in farming systems with limited external inputs. The intercropping of food grains with forage legumes could be an important management practice to fill the production gaps of food and feed in both quantity and quality for human food and animal feed and increase the profitability and sustainability of the system in tropical regions [4]. In different production systems, legumes are able to improve both crop production through sustained soil fertility and livestock production through increased availability of high-quality forage. Furthermore, one of the potential approaches to improve the availability of food and forage for households is the intercropping of cereals with herbaceous legumes [5]. A legume-cereal combination is the most common type of intercropping that occurs in annual crops, and the majority of successful 
intercrops grown worldwide are also cereal-legume production system [6].

Finger millet (Eleusine coracana) is one of the cereal species classified as orphan plants [7]. Orphan crops are crops of minor importance on a global scale, but they play a crucial role in the food and nutrition security and livelihoods of resource-poor farmers and consumers in developing countries. The term orphan refers to the negligence of crops by the international research community [8]. Akuja [9] reported that in Africa, finger millet is mainly produced in Uganda, Tanzania, Rwanda, Burundi, eastern Zaire, and Kenya and to a lesser extent in Ethiopia, Sudan, and Somalia. Finger millet (Eleusine coracana) is a small-seeded cereal grown in rain-fed conditions in low-rainfall areas of the world's semiarid tropics. It is a robust crop, capable of giving a reasonable grain yield in circumstances where other plants negligibly yield. Finger millet is a staple food in droughtprone areas of the world and is often considered a component of food security strategies [10]. In Africa, finger millet is grown by small farmers, who often grow it with grains, legumes, or vegetables. It is also important for its nutritive and cultural value, particularly in traditional, lowinput grain-based farming systems [11]. In Ethiopia, the current national average grain yield of this crop is $2.10 \mathrm{tha}^{-1}$, and in Bako 2.34-2.98 and 2.30-2.98 $\mathrm{tha}^{-1}$ in the research field and farmers' fields, respectively [12]. On the other hand, vetch is an annual forage legume that is well adapted and more promising as short-term forage crops and is widely adapted to the highlands and mid-elevations of Ethiopia. In addition, some research reports also show that it is possible to produce vetch from sea level to an altitude of 3,000 meters and that it is suitable for a wide range of rainfall, typically anything over $400 \mathrm{~mm}$ per year [13]. The production and/or propagation of this valuable forage legume requires seed availability. However, small farmers could not readily allocate separate plots from their limited land for vetch seed production.

Feed shortage both in quantity and quality is the main factor hampering the development of animal production in the crop-livestock production system [14]. Improved forage seed scarcity is one of the critical problems of forage production in areas where the land is dominated by food crops. However, recent research results in northern Ethiopia show that intercropping of finger millet with forage legumes was preferred by farmers and also had a yield advantage over single crops [15]. Therefore, it may be ideal to integrate vetch seed production with finger millet grain production through intercropping to achieve significant yields from the same plot with economical use of resources. Therefore, the aim of the study was to evaluate the grain/seed yield and the yield components of three species of vetch and finger millet intercropped at different sowing ratios under Bako conditions.

\section{Materials and Methods}

2.1. Description of the Study Area. The experiment was conducted during the main rainy season (June to November) in 2020 at Bako Agricultural Research Center (BARC), which is located in Oromia Regional State, West Shewa Zone, and Bako Tibe District, about $250 \mathrm{~km}$ from the capital, Addis Ababa, on the way to Nekemte Town. It is about $8 \mathrm{~km}$ away from Bako Town, at an altitude of 1,650 meters above sea level and at $09^{\circ} 66^{\prime} 00^{\prime \prime} \mathrm{N}$ latitude and $37^{\circ} 09^{\prime} 00^{\prime \prime} \mathrm{E}$ longitude.

. The area has a warm, humid climate with annual mean minimum and maximum temperatures of 14.4 and $29.3^{\circ} \mathrm{C}$, respectively. The area receives an annual rainfall of 1,605.1 mm mainly from May to October, with maximum rainfall from May to September (Figure 1). The dominant soil type of the area is Nitisol, which is characteristically reddish brown and loamy in texture with a $\mathrm{pH}$ falling in the range of very strongly acidic to strongly alkaline, as assessed byJones et al. [16]. As located in the tepid to cool subhumid mid-highland (SH2) agroecological zone, the area is a mixed farming zone surrounded by the Gibe River and lush natural vegetation. The area is known for its mixed livestock farming, producing corn (Zea mays L.), finger millet (Eleusine coracana), niger seed (Guizoita abyssinica, L.), hot pepper (Capsicum annuum L.), soybean (Glycine max L.), common bean (Phaseolus vulgaris L.), mango (Mangifera indica L.), banana (Musa spp.), and sugar cane (Saccharum officinarum L.) are widespread [17].

2.2. Experimental Materials. An improved variety of finger millet (Bako-09) and vetches (Vicia sativa, Vicia villosa, and Vicia atropurpurea) were used as test crops for the study. The finger millet variety (Bako-09) was released by the Bako Agricultural Research Center (BARC) in 2017 and is characterized by its erect growth habits. It is highly adaptable to medium and low altitudes [12]. Vetch species were introduced into BARC from the Holeta and Sinana Agricultural Research Centers and adapted to Bako conditions.

2.3. Treatments and Experimental Design. Treatment included three vetch species Vicia sativa (common vetch), Vicia villosa (hairy vetch), and Vicia atropurpurea (purple vetch) and five seeding ratios $(0: 100,100: 0,25: 75,50: 50$, and $75: 25 \%$ finger millet: vetch, respectively) in a randomized complete block design (RCBD) with three repetitions. The vetch species were intercropped between the rows of the finger, and sole species and finger millet were sown based on their respective recommended seed rates of $25 \mathrm{~kg} / \mathrm{ha}$ for Vicia villosa and Vicia atropurpurea, and $30 \mathrm{~kg} /$ ha for Vicia sativa [18] and finger millet $15 \mathrm{~kg} / \mathrm{ha}$ [12]. Both finger millet and vetch seeds were sown in their respective rows. The experiment consisted of three blocks; each block contained thirteen experimental units (plots) yielding thirtynine plots. The experimental plot size was $3 \mathrm{~m} * 4 \mathrm{~m}=12 \mathrm{~m}^{2}$. The spacing (space) between plots and blocks (replications) was $1 \mathrm{~m}$ and $1.5 \mathrm{~m}$, respectively. Plots in each block were randomly assigned to the thirteen treatments using the SAS software randomization method. The vetch species were sown after two weeks of finger millet planting according to the recommendation [19]. The treatment arrangement is shown in Table 1 below. 


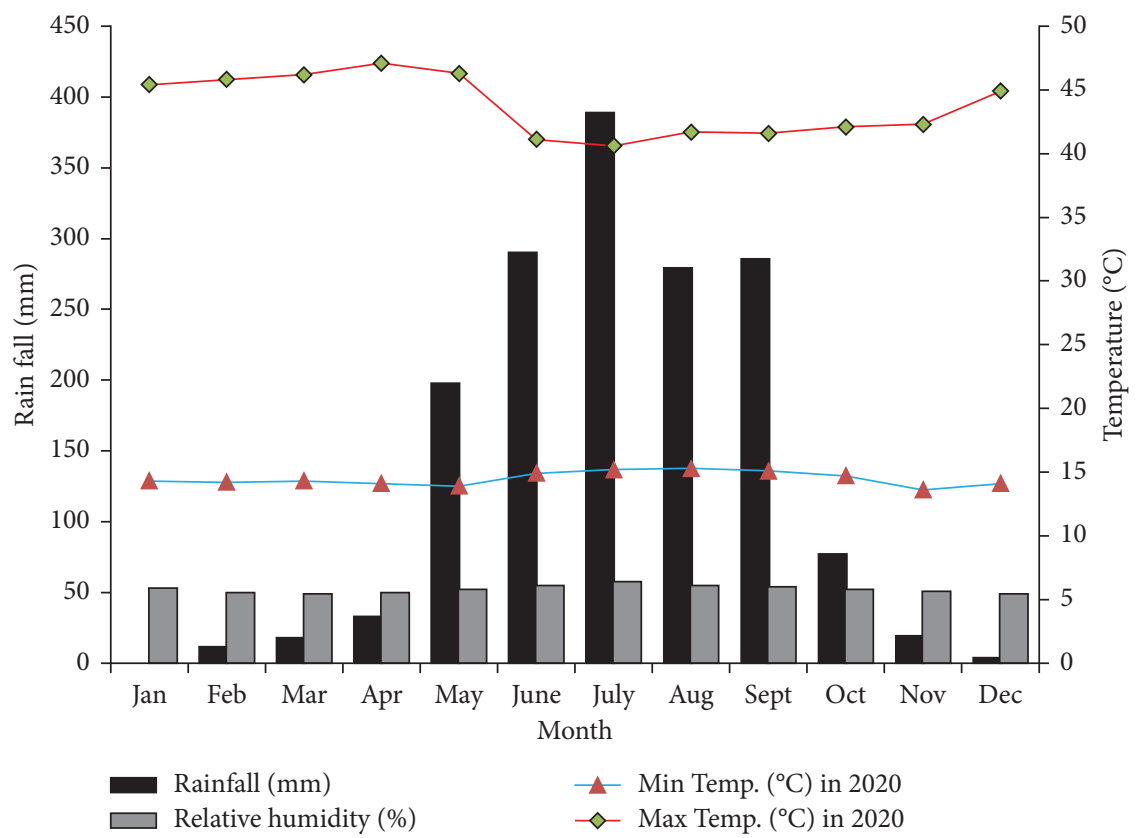

Figure 1: Monthly total rainfall $(\mathrm{mm})$, relative humidity $(\%)$, and mean minimum and maximum temperatures $\left({ }^{\circ} \mathrm{C}\right)$ of an experimental station in 2020. Source: Bako Agricultural Research Center Meteorology station unpublished data 2020.

TABle 1: Treatment arrangements of the experiment.

\begin{tabular}{|c|c|c|c|}
\hline \multirow{2}{*}{ Treatments } & \multirow{2}{*}{ Description } & \multicolumn{2}{|c|}{ Seeding ratios } \\
\hline & & Finger millet (\%) & Vetch $(\%)$ \\
\hline $\mathrm{T} 1$ & Sole finger millet(Eleusine coracana) & 100 & 0 \\
\hline $\mathrm{T} 2$ & Sole Vicia sativa & 0 & 100 \\
\hline T3 & Sole Vicia villosa & 0 & 100 \\
\hline $\mathrm{T} 4$ & Sole Vicia atropurpurea & 0 & 100 \\
\hline T5 & Finger millet + Vicia sativa & 25 & 75 \\
\hline T6 & Finger millet + Vicia sativa & 50 & 50 \\
\hline T7 & Finger millet + Vicia sativa & 75 & 25 \\
\hline $\mathrm{T} 8$ & Finger millet Vicia villosa & 25 & 75 \\
\hline T9 & Finger millet + Vicia villosa & 50 & 50 \\
\hline $\mathrm{T} 10$ & Finger millet + Vicia villosa & 75 & 25 \\
\hline T11 & Finger millet + atropurpurea & 25 & 75 \\
\hline $\mathrm{T} 12$ & Finger millet + atropurpurea & 50 & 50 \\
\hline $\mathrm{T} 13$ & Finger millet + atropurpurea & 75 & 25 \\
\hline
\end{tabular}

2.4. Land Preparation and Planting. The land was plowed and fined with tractors and finally leveled by day laborers to fine the soil. Fine seedbed plots were prepared before the experimental plots were laid out. The recommended fertilizer rate of $100 \mathrm{~kg} \mathrm{ha}^{-1}$ NPS and $64 \mathrm{~kg} \mathrm{ha}^{-1}$ urea [12] was applied at planting for all experimental units, except for the sole vetch (legume) plots, which received only $100 \mathrm{~kg} \mathrm{ha}^{-1}$ NPS. Seeds of finger millet (Eleusine coracana) and three species of vetch (Vicia sativa, Vicia villosa, and Vicia atropurpurea) were sown in alternating rows according to their seed rate proportions on wellprepared soil [20]. Weeding was performed by hand to eliminate the regrowth of unwanted plants and to encourage finger millet and vetch growth by increasing soil aeration. The plots were kept weed-free during the growing season.

\subsection{Data Collection Procedures}

2.5.1. Agronomic Parameters. For finger millet, agronomic parameters such as the number of heads per plant and number of fingers per head were counted, while plant height was measured with a measuring tape from five plants randomly selected from the middle rows of each plot at harvest. In the same way, the agronomic parameters of legumes (vetch) such as the number of branches per plant and the number of leaves per plant were counted from five randomly selected plants, and the plant height was measured by measuring tape from five plants selected from the middle rows of each plot.

2.5.2. Grain Yield and Yield Components of Finger Millet. At the full-grain maturity (146 days) recommended by Dessalegn et al. [12,] three medium finger millet rows were 
harvested per experimental plot to determine grain yield and yield components. Grain yield was calculated in $\mathrm{kg}$ per hectare. This was performed at $12 \%$ moisture content [9].

2.5.3. Seed Yield of Vetch Species. The inner rows of each plot intercropped with finger millet in different seeding ratios and three vetch species sown alone were harvested to determine seed yield. Since vetches have indeterminate growth habits with uneven seed maturity, [18] continuous visual observation of seed maturity was performed, mature pods per plot were sequentially collected, and total seed yield was determined from the inner rows after threshing and winnowing. Seed samples were collected and oven-dried at $100^{\circ} \mathrm{C}$ for 48 hours to adjust the moisture content to $10 \%$, a standard moisture content for legumes [21]. Seed yield (kg $\mathrm{ha}^{-1}$ ) was then calculated at $10 \%$ moisture content [22].

$$
\text { Grain yield }\left(\frac{\mathrm{kg}}{\mathrm{ha}}\right)=\frac{\text { plot yield }(\mathrm{kg}) \times 10,000}{\text { plot size in square metres }} \text {. }
$$

\subsection{System Productivity}

2.6.1. Land Equivalent Ratio and Relative Crowding Coefficient of Intercrops. The yield advantage of intercropping can be expressed using a variety of methods, the most common of which is the land equivalent ratio (LER) used to indicate biological efficiency and yield per unit area compared to the monoculture system; an LER greater than 1.0 implies that intercropping for that particular crop combination yielded more than growing the same number of stands of each crop as single crops, and if $L E R=1$, there are no advantages or disadvantages of intercropping in relation to single crops. An LER less than 1.0 implies that intercropping was less beneficial than sole cropping [23]. The land equivalent ratio determines the competitiveness of cereals (grass) and legumes in intercropping, i.e., it indicates the competitive relationship between species. It is the relative land area under single crops required to produce the yields obtained in intercropping. The number calculated is called the land equivalent ratio (LER), where the intercrop yields are divided by the pure stand yields for each crop in the intercrop system and the two numbers are added [24].

$\mathrm{LER}=\frac{\text { Inter cropped Finger millet }}{\text { Sole Finger millet }}+\frac{\text { Intercropped Vetch }}{\text { Sole Vetch }}$.

Yield advantages of intercrops compared to sole crops are often attributed to mutually complementary effects of the component crops, such as better overall use of available resources. In general, legumes in monoculture have higher yields compared to yields in an intercropping system. LER gives an indication of the amount of sole cropping required to achieve the same yield on a unit of intercropped land. In a maize-vetch intercropping system, Dawit and Nebi [25] suggested that the LER varied from 1.33 to 1.51 which indicated as the advantage of intercropping over sole crops because of the ability of the legumes to fix atmospheric N.
Hence, intercropping is most important to increase and diverse productivity per unit area as compared to sole cropping.

2.6.2. Relative Crowding Coefficient. The term relative crowding coefficient $(k)$ of plant species was proposed by Hall [26]. There is a measure of whether that species has produced more or less yield than expected. If a species has a coefficient less than, equal to, or greater than one, it means it produced less yield, the same yield, or more yield than expected [3]. If the relative crowding coefficient (RCC) is greater than, equal to, or less than one, there is a yield advantage, no difference, or a yield disadvantage. The relative performance of the two crops, the relative crowding coefficient (RCC) in the finger millet/vetch intercropping system was evaluated using the formula of Reddy [27]:

$$
\mathrm{RCC}=\frac{\mathrm{LFM}}{1-\mathrm{LFM}} \times \frac{\mathrm{LV}}{1-\mathrm{LV}},
$$

where $L F M=$ LER of finger millet and LV = LER of vetch.

2.7. Statistical Analysis. Data collected from experimental plots were summarized using Microsoft Excel 2013. The pooled data were subjected to the ANOVA procedure using the general linear model (GLM) of the SAS software (2009) version 9.3. Differences in significance between the treatment means were separated and compared using the least significant difference (LSD) test at a $5 \%$ level of significance or a $95 \%$ confidence interval. The statistical model for the data analysis was [28]:

$$
\begin{aligned}
y_{i j k} & =\mu+\alpha_{i}+\beta_{j}+(\alpha \beta)_{i j}+\varepsilon_{i j k}, \\
i & =1, \ldots, I, j=1, \ldots, J, k=1, \ldots, n_{i j} .
\end{aligned}
$$

The $\alpha_{i}$ and $\beta_{j}$ parameters represent the main effects and have the same general interpretation as the effect in a oneway ANOVA does. The $(\alpha \beta)_{i j}$ represents an interaction effect. The $\varepsilon_{i j k}$ represents random error.

\section{Results and Discussion}

3.1. Agronomic Performance of Finger Millet. The result showed that the species of intercropped vetch, seeding ratio, and their interaction had significantly $(P<0.05)$ influenced all measured traits of finger millet (Table 2). Plant height was one of the characteristics of finger millet that had shown differences between treatments. Plant height plays an important role in determining the yield of forage crops, which can be affected by intercropping. Plant height has the main contribution to forage and dry matter yield [29]. In this study, varieties with the tallest plant height showed better $\mathrm{DM}$ yields within their tested varieties. In general, plant height in a grain (grass) and legume mixture results from the mutual benefit of the grain (grass) and legume components [30]. The tallest and lowest plant heights of finger millet $(89.39$ and $81.07 \mathrm{~cm})$ were recorded from T10 and T7, respectively. This could be due to the highest plant density, which can force plants to move upward to receive sunlight, 
TABLE 2: Main effects and interaction effect of vetch species and seeding ratio on plant height, heads per plant, fingers per head, and leaf to stem ratio of finger millet.

\begin{tabular}{|c|c|c|c|}
\hline Factors & Plant height $(\mathrm{cm})$ & Heads per plant & Fingers per head \\
\hline \multicolumn{4}{|l|}{ Vetch species } \\
\hline Vspps1 & $84.28^{\mathrm{b}}$ & $3.14^{\mathrm{c}}$ & $6.11^{\mathrm{b}}$ \\
\hline Vspps2 & $86.09^{\mathrm{a}}$ & $4.58^{\mathrm{a}}$ & $7.00^{\mathrm{a}}$ \\
\hline Vspps3 & $84.86^{\mathrm{b}}$ & $3.75^{\mathrm{b}}$ & $5.44^{\mathrm{c}}$ \\
\hline Sole finger millet mean(T1) & 86.16 & 4.09 & 6.00 \\
\hline$P$ value & 0.0016 & 0.0001 & 0.0003 \\
\hline \multicolumn{4}{|l|}{ Seeding ratios } \\
\hline SR1 & $82.29^{\mathrm{c}}$ & $3.30^{c}$ & $5.56^{\mathrm{b}}$ \\
\hline SR2 & $85.48^{\mathrm{b}}$ & $3.93^{\mathrm{b}}$ & $6.11^{\mathrm{b}}$ \\
\hline SR3 & $87.45^{\mathrm{a}}$ & $4.24^{\mathrm{a}}$ & $6.89^{\mathrm{a}}$ \\
\hline$P$ value & 0.0001 & 0.0001 & 0.0012 \\
\hline \multicolumn{4}{|l|}{ Intercrops } \\
\hline Vspps $1 *$ SR1(T5) & $81.07^{\mathrm{e}}$ & $2.18^{\mathrm{f}}$ & $6.33^{\mathrm{cd}}$ \\
\hline Vspps $1 *$ SR2(T6) & $84.61^{\mathrm{c}}$ & $3.46^{\mathrm{e}}$ & $6.67^{\mathrm{b}}$ \\
\hline Vspps $1 *$ SR3(T7) & $86.16^{\mathrm{b}}$ & $3.78^{\mathrm{d}}$ & $6.33^{\mathrm{bc}}$ \\
\hline Vspps $2 *$ SR1(T8) & $82.97^{\mathrm{d}}$ & $4.12^{\mathrm{c}}$ & $6.33^{\mathrm{bc}}$ \\
\hline Vspps $2 *$ SR2(T9) & $85.89^{\mathrm{bc}}$ & $4.63^{\mathrm{b}}$ & $6.67^{\mathrm{b}}$ \\
\hline Vspps $2 *$ SR3(T10) & $89.39^{\mathrm{a}}$ & $4.89^{\mathrm{a}}$ & $8.00^{\mathrm{a}}$ \\
\hline Vspps3 $*$ SR1(T11) & $82.85^{\mathrm{d}}$ & $3.50^{\mathrm{e}}$ & $5.00^{\mathrm{d}}$ \\
\hline Vspps $3 *$ SR2(T12) & $85.92^{\mathrm{bc}}$ & $3.69^{d}$ & $5.08^{\mathrm{cd}}$ \\
\hline Vspps $3 *$ SR3(T13) & $86.81^{\mathrm{b}}$ & $4.06^{\mathrm{c}}$ & $6.33^{\mathrm{bc}}$ \\
\hline Mean & 85.08 & 3.82 & 6.19 \\
\hline SEM & 0.51 & 0.059 & 0.36 \\
\hline$P$ value & 0001 & 0001 & 0004 \\
\hline $\mathrm{Cv}(\%)$ & 1.03 & 2.67 & 10.02 \\
\hline
\end{tabular}

and the legumes' contribution to nitrogen fixation, which in turn contributes to vegetative growth. The current result was similar to the finding of Dawit and Nebi, [25], in which the highest plant heights for $V$. villosa and $V$. villosa intercropped treatments in a maize-vetch intercropping. On the other hand, this result contradicts the findings of Islam et al. [31], who pointed out that the plant height of sole pearl millet is higher than that of their respective intercrops with cowpea. The difference can be due to agroecology, rainfall, soil type, growing temperature, the variety used, and other climatic factors.

The heads per plant of finger millet were significantly affected by both species and seeding ratio and their interaction. The maximum heads per plant (4.89) were obtained from T10, while the minimum heads per plant (2.18) were recorded for T5. The number of fingers per head of finger millet was significantly $(P<0.05)$ influenced by the main effect and the interaction effect of vetch species and seeding ratios. Heads per plant in the current study ranged from 2.18 to 4.89 with a mean of 3.82 . This value is lower than that reported by Anteneh et al. [32] assessing the genetic diversity of finger millet genotypes at the Adet Agricultural Research Center (AARC), Koga irrigation site. The difference could be attributed to genotypes, agroecology, soil type, soil moisture, temperature, and other plant growth factors. The maximum and minimum (8.00 and 5.00) number of fingers per head were obtained from T10 and T11, respectively. This could be due to varietal differences and space allocation to the intercrops and the higher seeding ratios that may have used all the production resources than lower seeding ratios. The number of fingers per head of finger millet in this study was higher than the value reported by AARC. On the other hand, the leaf-to-stem ratio of finger millet was not significantly $(P>0.05)$ affected by any of the factors and their interaction.

\subsection{Agronomic Performance of Vetch}

3.2.1. Plant Height. Vetch plant height was significantly affected $(P<0.05)$ by species, seeding ratios, and cover crops when forage was harvested at 50\% flowering (Table 3). Vetch species intercropped with finger millet had a higher plant height compared to their corresponding sole crops. This could be due to the natural struggling mechanism of each crop against light and mainly due to the competition between species. Intercropped stands were higher than pure vetch stands due to competition between species. This suggests that intercrops are moving toward sunlight, which is critical for photosynthesis. The present result contradicts the report by Ojo et al. [33], who found that the plant height of Panicum maximum in Lablab purpureus was not significantly different from that of sole 14 weeks after planting. The difference between the results could be attributed to factors such as soil type, legume and grass type as harvest date, and other management conditions. 
TABLE 3: Effect of vetch species and seeding ratio on plant height $(\mathrm{cm})$, leaves per plant, branches per plant, pods per plant, and seeds per pod of vetch.

\begin{tabular}{|c|c|c|c|c|c|}
\hline Factors & Plant height $(\mathrm{cm})$ & Leaves per plant & Branches per plant & Pods per plant & Seeds per pod \\
\hline \multicolumn{6}{|l|}{ Vetch species } \\
\hline Vspps1 & $79.11^{\mathrm{c}}$ & $31.67^{\mathrm{a}}$ & $1.98^{\mathrm{c}}$ & $6.26^{\mathrm{b}}$ & $6.95^{\mathrm{a}}$ \\
\hline Vspps2 & $155.67^{\mathrm{a}}$ & $24.11^{b}$ & $3.31^{\mathrm{a}}$ & $8.39^{\mathrm{a}}$ & $4.37^{\mathrm{c}}$ \\
\hline Vspps3 & $132.44^{\mathrm{b}}$ & $22.67^{\mathrm{b}}$ & $2.84^{\mathrm{b}}$ & $3.77^{\mathrm{c}}$ & $4.78^{\mathrm{b}}$ \\
\hline$P$ value & 0.0001 & 0.0001 & 0.0001 & 0.0001 & 0.0001 \\
\hline \multicolumn{6}{|l|}{ Sole vetch species } \\
\hline Sole Vspps1(T2) & $73.67^{\mathrm{c}}$ & $36.00^{\mathrm{a}}$ & 1.22 & $8.45^{\mathrm{b}}$ & $7.51^{\mathrm{a}}$ \\
\hline Sole Vspps2(T3) & $145.33^{\mathrm{a}}$ & $30.00^{\mathrm{b}}$ & 1.26 & $10.19^{\mathrm{a}}$ & $4.33^{\mathrm{b}}$ \\
\hline Sole Vspps3(T4) & $129.67^{\mathrm{b}}$ & $29.67^{b}$ & 1.23 & $6.89^{c}$ & $4.70^{\mathrm{b}}$ \\
\hline$P$ value & 0.0001 & 0.0447 & 0.4771 & 0.0008 & 0.0001 \\
\hline \multicolumn{6}{|l|}{ Seeding ratios } \\
\hline SR1 & $125.00^{\mathrm{a}}$ & $28.78^{\mathrm{a}}$ & $2.25^{\mathrm{b}}$ & $6.46^{\mathrm{a}}$ & $5.58^{\mathrm{a}}$ \\
\hline SR2 & $118.67^{\mathrm{b}}$ & $25.67^{\mathrm{b}}$ & $2.91^{\mathrm{a}}$ & $6.14^{\mathrm{b}}$ & $5.51^{\mathrm{a}}$ \\
\hline SR3 & $115.56^{\mathrm{b}}$ & $24.00^{\mathrm{b}}$ & $2.24^{\mathrm{b}}$ & $5.83^{\mathrm{c}}$ & $5.01^{\mathrm{b}}$ \\
\hline$P$ value & 0.0052 & 0.0019 & 0.0001 & 0.0005 & 0.0175 \\
\hline \multicolumn{6}{|l|}{ Intercrops } \\
\hline Vspps $1 * \mathrm{SR} 1(\mathrm{~T} 5)$ & $85.33^{\mathrm{e}}$ & $35.00^{\mathrm{a}}$ & $2.35^{\mathrm{b}}$ & $6.56^{\mathrm{b}}$ & $7.49^{\mathrm{a}}$ \\
\hline Vspps $1 *$ SR2(T6) & $77.33^{\text {ef }}$ & $29.67^{\mathrm{bc}}$ & $2.32^{\mathrm{b}}$ & $6.35^{\mathrm{bc}}$ & $7.21^{\mathrm{ab}}$ \\
\hline Vspps $1 *$ SR3(T7) & $74.67^{\mathrm{f}}$ & $30.33^{\mathrm{ab}}$ & $2.13^{\mathrm{cd}}$ & $5.88^{\mathrm{c}}$ & $6.16^{\mathrm{b}}$ \\
\hline Vspps $2 *$ SR $1(\mathrm{~T} 8)$ & $154.00^{\mathrm{a}}$ & $26.33^{\mathrm{bcd}}$ & $3.32^{\mathrm{ab}}$ & $8.64^{\mathrm{a}}$ & $4.36^{\mathrm{c}}$ \\
\hline Vspps $2 *$ SR2(T9) & $146.33^{\mathrm{ab}}$ & $24.67^{\text {cde }}$ & $3.35^{\mathrm{a}}$ & $8.42^{\mathrm{ab}}$ & $4.43^{\mathrm{c}}$ \\
\hline Vspps $2 *$ SR3(T10) & $142.67^{\mathrm{bc}}$ & $21.33^{\mathrm{de}}$ & $2.13^{\mathrm{cd}}$ & $8.12^{\mathrm{ab}}$ & $4.31^{\mathrm{c}}$ \\
\hline Vspps3 $*$ SR1(T11) & $135.67^{\mathrm{cd}}$ & $25.00^{\text {cde }}$ & $2.19^{\mathrm{bc}}$ & $4.18^{\mathrm{d}}$ & $4.90^{\mathrm{c}}$ \\
\hline Vspps $3 *$ SR2(T12) & $132.33^{\mathrm{d}}$ & $22.67^{\mathrm{de}}$ & $2.16^{\mathrm{cd}}$ & $3.65^{\mathrm{de}}$ & $4.88^{\mathrm{c}}$ \\
\hline Vspps3 $*$ SR3(T13) & $129.33^{\mathrm{d}}$ & $20.33^{\mathrm{e}}$ & $2.15^{\mathrm{cd}}$ & $3.49^{\mathrm{e}}$ & $4.56^{\mathrm{c}}$ \\
\hline Mean & 119.74 & 26.15 & 2.71 & 6.14 & 5.37 \\
\hline SEM & 2.961 & 1.725 & 0.079 & 0.187 & 0.239 \\
\hline$P$ value & 0.0001 & 0.0002 & 0.0001 & 0.0001 & 0.0001 \\
\hline $\mathrm{Cv}(\%)$ & 4.42 & 11.43 & 5.11 & 5.26 & 7.71 \\
\hline
\end{tabular}

a-b Means with different letters in a column are significantly different $(P<0.05$. Vspps $=$ vetch species, $\mathrm{SR}=$ seeding ratio, Cm $=$ centimeter, Plht $=$ plant height, $\mathrm{LPP}=$ leaves per plant, $\mathrm{BPP}=$ branches per plant, $\mathrm{Pdpp}=$ pods per plant, spp = seeds per pod,.Vspps $1=$ vetch species 1 (Vicia sativa), Vspps $2=$ vetch species 2 (Vicia villosa), and Vspps $3=$ vetch species 3 (Vicia atropurpurea).

In this study, the highest plant height was recorded for intercropped Vicia villosa (VV2) and the lowest is for intercropped Vicia sativa (VV1) valued at $157.67 \mathrm{~cm}$ and $79.11 \mathrm{~cm}$, respectively. Moreover, Vicia villosa (T3) had the highest plant height among the soles followed by Vicia atropurpurea (T4) and Vicia sativa (T2) $(145.33 \mathrm{~cm}$, $129.67 \mathrm{~cm}$, and $73.67 \mathrm{~cm}$, respectively). The interaction of species and seeding ratios showed a significant difference $(P<0.05)$ for plant height at the forage harvesting stage. The maximum and minimum plant heights (154.00 and $85.33 \mathrm{~cm}$, respectively) were obtained from T10 and T5. In this study, analysis of variance revealed that with increasing seeding ratio of finger millet there was a decrease in plant height of vetch for all the tested species. This could be due to the suppressive effect of the cereal over the companion legume. Generally, earlier research reports have pointed out that plant height is the major attributor involved in the forage yield of grass and legumes associated with growth and biomass.

3.2.2. Leaves per Plant. Leaf number determines the photosynthetic capacity of a plant. Leaves per plant of vetch were significantly affected $(P<0.05)$ by species, seeding ratios, and their interaction at the forage harvest stage (Table 3 ). The leaves per plant of three vetch species intercropped with finger millet at different seeding ratios were lower than leaves per plant of their respective sole crops of each species. The number of leaves per plant of vetch for all the tested species was declined with an increasing seeding ratio of finger millet. This shows that leaf development of intercropped vetch was hampered by the dominance of finger millet in nutrients, moisture, and sunlight utilization. Analysis of variance for an interaction effect of variety and seeding ratio showed that $\mathrm{T} 5 \mathrm{had}$ produced the highest (35) leaves per plant, while the lowest leaves per plant (20.33) were obtained from T13. This result is similar to the finding of Azraf-ul-Haq et al. [34], in which intercropped sorghum produced a smaller number of leaves per plant than monocropped sorghum.

3.2.3. Branches per Plant. The number of branches per plant of vetch species was significantly affected $(P<0.05)$ by variety, seeding ratio, and their interaction (Table 3 ). The number of branches per plant of the vetch varieties varied between 2.13 and 3.35 with a mean value of 2.71. The maximum number of branches per plant (3.34) was counted for T9. This could be due to the balanced 
population of the two intercrops, which enabled the legume to get optimum soil nutrients, moisture, space, and light to establish well and produce the maximum branches. Alemu et al. [19] reported a higher number of branches than the results obtained in this study. The possible difference could be cropping system, agroecology, soil fertility, soil moisture, management practices, and other growth plant factors.

3.2.4. Pods per Plant. Pods per plant of vetch had shown significant difference $(P<0.05)$ for species, seeding ratios, and intercropping interaction (Table 3 ). In pure stands of vetch, there was also a significant difference $(P<0.05)$ among the tested varieties for pods per plant and the highest number of pods per plant (10.19) was recorded for Vicia villosa and the lowest number of pods per plant (6.89) was from sole Vicia atropurpurea. Analysis of the interaction effect of species and seeding ratio also indicated variation among the treatment combinations. Accordingly, the highest pods per plant (8.64) of the intercrops were recorded from T8. On the other hand, T13 gave the lowest (3.49) number of pods per plant. This could be due to varietal differences and other growth factors.

3.2.5. Seeds per Pod. The analysis of variance showed that seeds per pod of vetch were significantly $(P<0.05)$ affected by the main effect of intercropping (Table 3 ). The maximum seeds per pod (7.49) were obtained from T5. In this study, the highest pods per plant recorded in T8 (Vicia villosa) could not match with its seeds per pod. This could be due to the presence of some empty pods (seedless pods) in Vicia villosa [35].

3.3. Grain/Seed Yields of Finger Millet and Vetch. In this study, the grain yield of finger millet was significantly $(P<0.05)$ affected by vetch species, seeding ratio, and intercropping (Table 4 ). The highest grain yield of finger millet $\left(2288.92 \mathrm{~kg} \mathrm{ha}^{-1}\right)$ was harvested from $\mathrm{T} 1$ followed by T10 (2058.75 $\left.\mathrm{kg} \mathrm{ha}^{-1}\right)$.

This result showed that there is a $230.17 \mathrm{~kg}$ of finger millet grain yield difference without considering the yield of vetch produced from the intercrop. Moreover, a comparison of intercropped treatment combinations revealed that T10 and T7 statistically gave the same and the highest grain yield of finger millet with the former is numerically higher than the latter. This result is similar to the finding of Bitew et al. [36], who indicated that finger millet-haricot bean intercropping at a 100:50 planting ratio gave the highest grain yield. This study also revealed that the seed yield of vetch species was significantly varied $(P<0.05)$ for the tested treatments. The main effects of species and seeding ratio, and their interaction significantly affected the seed yield of vetch. Maximum and minimum seed yields $(236.19$ and $106.45 \mathrm{~kg}$ $\mathrm{ha}^{-1}$ ) were harvested from $\mathrm{T} 5$ and $\mathrm{T} 10$, respectively. This value matches with the seed per pod value we discussed above but not with pods per plant for reasons indicated earlier. Seed yield of vetch was increased with the increasing
TABLE 4: Grain/seed yields of finger millet and vetch as affected by species, seeding ratio, and intercropping.

\begin{tabular}{|c|c|c|}
\hline \multirow{2}{*}{$\begin{array}{l}\text { Factors } \\
\text { Vetch species }\end{array}$} & \multicolumn{2}{|c|}{ Grain/seed yield $\left(\mathrm{kg} \mathrm{ha}^{-1}\right)$} \\
\hline & Finger millet & Vetch \\
\hline Vspps1 & $1606.32^{\mathrm{ab}}$ & $155.14^{\mathrm{a}}$ \\
\hline Vspps2 & $1670.51^{\mathrm{a}}$ & $117.59^{\mathrm{c}}$ \\
\hline Vspps3 & $1369.46^{\mathrm{b}}$ & $139.89^{\mathrm{b}}$ \\
\hline Sole finger millet (T1) & $2288.92^{\mathrm{a}}$ & - \\
\hline$P$ value & 0.0001 & 0.0001 \\
\hline \multicolumn{3}{|l|}{ Sole vetch species } \\
\hline Sole Vspps1(T2) & - & $585.51^{\mathrm{a}}$ \\
\hline Sole Vspps2(T3) & - & $353.74^{\mathrm{c}}$ \\
\hline Sole Vspps3(T4) & - & $427.08^{b}$ \\
\hline$P$ value & - & 0.0001 \\
\hline \multicolumn{3}{|l|}{ Seeding ratios } \\
\hline SR1 & $1290.86^{\mathrm{c}}$ & $177.07^{\mathrm{a}}$ \\
\hline SR2 & $1537.26^{\mathrm{b}}$ & $124.18^{\mathrm{b}}$ \\
\hline SR3 & $1818.17^{\mathrm{a}}$ & $111.38^{\mathrm{c}}$ \\
\hline$P$ value & 0.0001 & 0.0001 \\
\hline \multicolumn{3}{|l|}{ Intercrops } \\
\hline $\mathrm{Vspps}_{1} * \mathrm{SR}_{1}(\mathrm{~T} 5)$ & $1342.79^{\mathrm{d}}$ & $236.19^{\mathrm{a}}$ \\
\hline $\mathrm{Vspps}_{1} * \mathrm{SR}_{2}(\mathrm{~T} 6)$ & $1732.00^{\mathrm{C}}$ & $118.81^{\mathrm{d}}$ \\
\hline $\mathrm{Vspps}_{1} * \mathrm{SR}_{3}(\mathrm{~T} 7)$ & $1936.75^{\mathrm{bc}}$ & $110.46^{\mathrm{de}}$ \\
\hline $\mathrm{Vspps}_{2} * \mathrm{SR}_{1}(\mathrm{~T} 8)$ & $1346.46^{\mathrm{d}}$ & $129.79^{c}$ \\
\hline $\mathrm{Vspps}_{2} * \mathrm{SR}_{2}(\mathrm{~T} 9)$ & $1595.83^{\mathrm{c}}$ & $116.52^{\mathrm{d}}$ \\
\hline $\mathrm{Vspps}_{2} * \mathrm{SR}_{3}(\mathrm{~T} 10)$ & $2058.75^{\mathrm{b}}$ & $106.45^{\mathrm{e}}$ \\
\hline $\mathrm{Vspps}_{3} * \mathrm{SR}_{1}(\mathrm{~T} 11)$ & $1183.33^{\mathrm{e}}$ & $165.23^{\mathrm{b}}$ \\
\hline $\mathrm{Vspps}_{3} * \mathrm{SR}_{2}(\mathrm{~T} 12)$ & $1283.96^{\mathrm{de}}$ & $137.20^{\mathrm{C}}$ \\
\hline $\mathrm{Vspps}_{3} * \mathrm{SR}_{3}(\mathrm{~T} 13)$ & $1641.08^{\mathrm{c}}$ & $117.23^{\mathrm{d}}$ \\
\hline Mean & 1640.99 & 137.54 \\
\hline SEM & 48.71 & 2.948 \\
\hline$P$ value & 0001 & 0001 \\
\hline $\mathrm{Cv}(\%)$ & 5.14 & 3.71 \\
\hline
\end{tabular}

${ }^{\mathrm{a}-\mathrm{b}}$ Means with different letters in a column are significantly different $(P<0.05)$. SEM $=$ standard error of mean, $P=$ probability, $\mathrm{kg} \mathrm{ha}^{-1}=$ kilogram per hectare, Vspps1 $=$ vetch species 1 (Vicia sativa), Vspps $2=$ vetch species 2 (Vicia villosa), and Vspps $3=$ vetch species 3 (Vicia atropurpurea).

seeding ratio of the legume. This could be due to more space and nutrient utilization of the crop that favored it to establish and produce more seed than the lower seeding ratios.

\subsection{System Productivity}

3.4.1. Land Equivalent Ratio. The land equivalent ratio (LER) is the most commonly used indicator for the biological efficiency and yield per unit area of land as compared to monocropping systems. LER greater than 1.0 implies that for a particular crop combination, intercropping yield is more than growing the same number of stands of each crop as sole crops, whereas LER of less than 1.0 implies that intercropping was less beneficial than sole cropping [37].

The land equivalent ratio (LER) in this study showed significant variation $(P<0.05)$ for all the treatment combinations (Table 5). Land equivalent ratio of grain yield of finger millet (LERFM) was increased with increasing seeding ratios of finger millet and decreasing seeding ratio of vetch, and vice versa. Moreover, the LER of vetch (LERV) was also increased with an increase in its seeding ratio. This is in 
TABLE 5: Land equivalent ratio and relative crowding coefficient as affected by intercropping of finger millet and vetch species.

\begin{tabular}{|c|c|c|c|c|}
\hline Treatments & LERFM & LERV & LER & RCC \\
\hline $\mathrm{Vspps}_{1} * \mathrm{SR}_{1}(\mathrm{~T} 5)$ & $0.59^{c}$ & $0.430^{\mathrm{a}}$ & $1.016^{\mathrm{bcd}}$ & $1.090^{\mathrm{cd}}$ \\
\hline $\mathrm{Vspps}_{1} * \mathrm{SR}_{2}(\mathrm{~T} 6)$ & $0.757^{\mathrm{b}}$ & $0.367^{\mathrm{abc}}$ & $1.120^{\mathrm{abc}}$ & $1.780^{\mathrm{bc}}$ \\
\hline $\mathrm{Vspps}_{1} * \mathrm{SR}_{3}(\mathrm{~T} 7)$ & $0.847^{\mathrm{a}}$ & $0.300^{\mathrm{bc}}$ & $1.140^{\mathrm{ab}}$ & $2.417^{\mathrm{ab}}$ \\
\hline $\mathrm{Vspps}_{2} * \mathrm{SR}_{1}(\mathrm{~T} 8)$ & $0.587^{\mathrm{c}}$ & $0.400^{\mathrm{ab}}$ & $0.993^{\mathrm{cd}}$ & $1.053^{\mathrm{d}}$ \\
\hline $\mathrm{Vspps}_{2} * \mathrm{SR}_{2}(\mathrm{~T} 9)$ & $0.700^{\mathrm{b}}$ & $0.323^{\mathrm{abc}}$ & $1.020^{\mathrm{abcd}}$ & $1.283^{\mathrm{cd}}$ \\
\hline $\mathrm{Vspps}_{2} * \mathrm{SR}_{3}(\mathrm{~T} 10)$ & $0.900^{\mathrm{a}}$ & $0.246^{\mathrm{c}}$ & $1.146^{\mathrm{a}}$ & $3.00^{\mathrm{a}}$ \\
\hline $\mathrm{Vspps}_{3} * \mathrm{SR}_{1}(\mathrm{~T} 11)$ & $0.520^{\mathrm{d}}$ & $0.400^{\mathrm{ab}}$ & $0.913^{\mathrm{d}}$ & $0.770^{\mathrm{d}}$ \\
\hline $\mathrm{Vspps}_{3} * \mathrm{SR}_{2}(\mathrm{~T} 12)$ & $0.560^{\mathrm{cd}}$ & $0.337^{\mathrm{abc}}$ & $0.862^{\mathrm{d}}$ & $0.677^{\mathrm{d}}$ \\
\hline $\mathrm{Vspps}_{3} * \mathrm{SR}_{3}(\mathrm{~T} 13)$ & $0.720^{\mathrm{b}}$ & $0.307^{\mathrm{bc}}$ & $1.023^{\mathrm{abcd}}$ & $1.173^{\mathrm{cd}}$ \\
\hline SEM & 0.021 & 0.041 & 0.044 & 0.242 \\
\hline$P$ value & 0.0001 & 0.049 & 0.04 & 0.0001 \\
\hline
\end{tabular}

agreement with the findings of Dereje [38], who indicated that the LER of oat and vetch mixture was increased with increasing seed proportions and vice versa. All the highest seeding ratios of the three vetch species were statistically similar in their partial LER. The partial LER of vetch in all the treatment combinations was below 0.5 indicating the dominance of finger millet over vetch in an intercropping system. However, in this study $75 \%$ of the treatment combinations gave acceptable total land equivalent ratio (LER) $>1$, indicating the advantage of intercropping over monocropping. The highest (1.146) total LER recorded from $75 \%$ finger millet $+25 \%$ Vicia villosa shows that about $15 \%$ of a hectare of land was saved to grow both crops in pure stand to produce the grain yields obtained by their combination. LER in this study ranged from 0.86 to 1.146 , and the highest (1.146) was obtained from T10 (75\% Finger millet $+25 \%$ Vicia villosa) and the lowest (0.86) was from T12 (50\% Finger millet $+50 \%$ Vicia atropurpurea).

3.4.2. Relative Crowding Coefficient. Relative crowding coefficient (RCC) indicates the competitive ability of the component species. In sowing intercrops, the higher RCC of the component species indicates that it is more competent. Intercropping of finger millet with the three vetch species at different seeding ratios had significantly $(P<0.05)$ affected the relative crowding coefficient (RCC) of the intercrops (Table 5).

Accordingly, this study showed that Finger millet (Eleusine coracana) intercropped with Vicia villosa at a seeding ratio of 75\%:25\% of Finger millet: vetch, respectively, had produced the highest RCC of 3.00. On the other hand, the lowest RCC was obtained from intercropping of $25 \%$ finger millet with $75 \%$ Vicia atropurpurea (T11), and this report was similar to the result of others [39].

\section{Conclusion}

Mixed crop-livestock production was the dominant farming system in the study areas practiced for reducing livelihood risks, optimizing the use of limited resources (land), and diversifying income sources for more security in maintaining household livings. In Ethiopia, the conversion of grazing land to arable land and a single cropping system is exacerbating forage shortages in a very desperate way. Intercropping of vetch and finger millet has shown that it is possible to achieve significant grain/seed yield in a food-feed production strategy. The compatibility indices used in this study showed that $75 \%$ finger millet intercropped with $25 \%$ Vicia villosa was superior for the measured traits. Thus, it can be concluded that it is possible to produce both finger millet and vetch in a compatible way as a food/feed production strategy to alleviate the food and feed problem, thereby improving the livelihood of small-scale farmers in Ethiopia.

\section{Data Availability}

All data supporting the conclusions of this study are included in this article.

\section{Conflicts of Interest}

The authors declare that they have no conflicts of interest.

\section{Acknowledgments}

The authors would like to thank the Oromia Agricultural Research Institute for its contribution to the financing and the Bako Agricultural Research Center for the provision of experimental plots together with all necessary inputs to execute the project entitled: evaluation of grain/seed yield and yield components of three vetch species and finger millet intercropped at various seeding ratios under Bako condition, Ethiopia.

\section{References}

[1] H. C. J. Godfray and T. Garnett, "Food security and sustainable intensification," Philosophical Transactions of the Royal Society B: Biological Sciences, vol. 369, no. 1639, Article ID 20120273, 2014.

[2] P. Jakhar, P. P. Adhikary, B. S. Naik, and M. Madhu, "Finger millet (Eleusine coracana)-groundnut (Arachis hypogaea) strip cropping for enhanced productivity and resource conservation in uplands of Eastern Ghats of Odisha," Indian Journal of Agronomy, vol. 60, no. 3, pp. 365-371, 2015. 
[3] E. M. Taha and A. M. El-Mahdy, "Land equivalent ratio as a reference for relative crowding coefficient and aggressivity of intercropped plant species," Middle East Journal of Agriculture Research, vol. 3, no. 3, pp. 576-585, 2014.

[4] G. Kebede, G. Assefa, F. Feyissa, and A. Mengistu, "Forage legumes in crop-livestock mixed farming systems-a review," International Journal of Livestock Research, vol. 6, no. 4, pp. 1-18, 2016.

[5] B. E. Mthembu, T. M. Everson, and C. S. Everson, "Intercropping for enhancement and provisioning of ecosystem services in smallholder, rural farming systems in KwaZuluNatal Province, South Africa: a review," Journal of Crop Improvement, vol. 33, no. 2, pp. 145-176, 2019.

[6] M. D. Belel, R. A. Halim, M. Y. Rafii, and H. M. Saud, "Intercropping of corn with some selected legumes for improved forage production: a review," Journal of Agricultural Science, vol. 6, no. 3, p. 48, 2014.

[7] S. Sood, A. Kumar, B. K. Babu et al., "Gene discovery and advances in finger millet [Eleusine coracana (L.) gaertn.] genomics-an important nutri-cereal of future," Frontiers of Plant Science, vol. 7, p. 1634, 2016.

[8] Z. Tadele, "Orphan crops: their importance and the urgency of improvement," Planta, vol. 250, no. 3, pp. 677-694, 2019.

[9] T. E. Akuja, "Effect of legume intercrop management practices and inorganic nitrogen application on growth and yield of finger millet (Eleusine coracana L.)," M. Sc. Thesis, University of Nairobi, Nairobi, Kenya, 1995.

[10] T. Mulualem and A. Melak, "A survey on the status and constraints of finger millet (Eleusine coracana L.) production in Metekel Zone, North Western Ethiopia," Direct Research Journal of Agriculture and Food Science, vol. 1, no. 5, pp. 67-72, 2013.

[11] P. L. Mafongoya, A. Bationo, J. Kihara, and B. S. Waswa, "Appropriate technologies to replenish soil fertility in southern Africa," Nutrient Cycling in Agroecosystems, vol. 76, no. 2-3, pp. 137-151, 2006.

[12] K. Dessalegn, D. Lule, M. Debela et al., "Genotype by environment interaction and grain yield stability of Ethiopian black seeded finger millet genotypes," African Crop Science Journal, vol. 27, no. 2, pp. 281-294, 2019.

[13] A. Mengistu, G. Kebede, G. Asefa, and F. Feyisa, "Descriptions and characteristics of cultivated forage crops growing under different agro-ecological zones in Ethiopia," International Journal of Agriculture and Biosciences, vol. 6, no. 5, pp. 238-247, 2017.

[14] A. L. Duguma and J. K. Debsu, "Determinants of livestock production development of smallholder farmers," Journal of Applied Sciences \& Environmental Management, vol. 23, no. 8, pp. 1535-1540, 2019.

[15] B. Derebe, A. Worku, Y. Chanie, and A. Wolie, "On-farm participatory evaluation and selection of legumes intercropped with finger millet (Eleusine coracana L) in Western Amhara," Heliyon, vol. 7, no. 11, Article ID e08319, 2021.

[16] J. W. Jones, G. Hoogenboom, C. H. Porter et al., "The DSSAT cropping system model," European Journal of Agronomy, vol. 18, no. 3-4, pp. 235-265, 2003.

[17] A. Dabesa and T. Tana, "Response of soybean (Glycine max 1.(merrill)) to bradyrhizobium inoculation, lime, and phosphorus applications at Bako, Western Ethiopia," International Journal of Agronomy, vol. 2021, Article ID 6686957, 12 pages, 2021.

[18] K. Gezahagn, "Morpho-agronomic performance of vetch species and their accessions grown under nitosol and vertisol conditions in the central highlands of Ethiopia," Agriculture \& Food Security, vol. 7, p. 90, 2018.

[19] T. Alemu, Evaluation of Under-Sowing Vetch in Sorghum for Intensifying Existing Production Systems: Reducing Land Degradation and Farmers' Vulnerability to Climate Change in The Highland Dry Areas of North-Western Ethiopia, Technical Report of Experimental Activities, International Center for Agricultural Research in the Dry Areas (ICARDA), Beirut, Lebanon, 2016, https://www.icarda.org/.

[20] D. Diba and D. Geleti, "Effects of seed proportion and planting pattern on dry matter yield, compatibility and nutritive value of Panicum coloratum and Stylosanthes guianensis mixtures under Bako Condition, Western Oromia, Ethiopia," Science, Technology and Arts Research Journal, vol. 2, no. 4, pp. 56-61, 2013.

[21] B. Abebe, Agronomy Research Manual, Part III Formulae and Tables, IAR, Addis Ababa, Ethiopia, 1979.

[22] R. C. Muchow, "Comparative productivity of maize, sorghum and pearl millet in a semi-arid tropical environment I. Yield potential," Field Crops Research, vol. 20, no. 3, pp. 191-205, 1989.

[23] Onwueme and Sinha, Field Crop Production in Tropical Africa, Principles and Practice, CTA (Technical Center for Agriculture and Rural Cooperation), Wageningen, The Netherlands, 1991.

[24] P. Devaseanapathy, T. Ramesh, and B. Gangwar, Efficiency Indices for Agricultural Management Research, NIPA, New Delhi, India, 2008.

[25] D. Abate and N. Husen, "Effect of vetch varieties intercropped with maize on forage and maize yield performance in different agro-ecologies of West Arsi and East Showa Zone of Oromia, Ethiopia," Journal of Biology, Agriculture and Healthcare, vol. 7, no. 19, pp. 43-48, 2017.

[26] R. Hall, "Analysis of the nature of interference between plants of different species. I. Concepts and extension of the de Wit analysis to examine effects," Australian Journal of Agricultural Research, vol. 25, no. 5, pp. 739-747, 1974.

[27] R. S. Reddy, Principles of Agronomy, Kaliyani Publishers, New Delhi, India, 1999.

[28] J. Choi, "Projection analysis for two-way variance components," Journal of the Korean Data and Information Science Society, vol. 25, no. 3, pp. 547-554, 2014.

[29] D. N. Dhumale and S. N. Mishra, "Character association between forage yield and its components in oats," Indian Journal of Agricultural Sciences, vol. 49, pp. 918-924, 1979.

[30] T. Turemen, T. Saglamtimur, V. Tansi, and H. Baytekin, "Performance of annual ryegrass and common vetch in association under different ratios," Crop and Pasture Science, vol. 5, pp. 69-78, 1990.

[31] N. Islam, M. S. I. Zamir, S. M. U. Din et al., "Evaluating the intercropping of millet with cowpea for forage yield and quality," American Journal of Plant Sciences, vol. 9, pp. 1781-1793, 2018.

[32] D. Anteneh, F. Mekbib, T. Tadesse, and Y. Dessalegn, "Genetic diversity among lowland finger millet (Eleusine coracana (L) gaertn) accessions," Ethiopian Journal of Agricultural Sciences, vol. 29, no. 2, pp. 93-108, 2019.

[33] V. O. A. Ojo, P. A. Dele, T. A. Amole et al., "Effect of intercropping Panicum maximum var. Ntchisi and Lablab purpureus on the growth, herbage yield and chemical composition of Panicum maximum var. Ntchisi at different harvesting times," Pakistan Journal of Biological Sciences, vol. 16, no. 22, pp. 1605-1608, 2013.

[34] A. H. M. A. D. Azraf-ul-Haq, R. Ahmad, N. Mahmood, and A. Tanveer, "Performance of forage sorghum intercropped 
with forage legumes under different planting patterns," Pakistan Journal of Botany, vol. 39, no. 2, pp. 431-439, 2007.

[35] L. Kissing Kucek, H. Riday, B. P. Rufener et al., "Pod dehiscence in hairy vetch (Vicia villosa Roth)," Frontiers of Plant Science, vol. 11, p. 82, 2020.

[36] Y. Bitew, G. Alemayehu, E. Adgo, and A. Assefa, "Competition, production efficiency and yield stability of finger millet and legume additive design intercropping," Renewable Agriculture and Food Systems, vol. 36, no. 1, pp. 108-119, 2021.

[37] A. I. Tofa, T. Ademulegun, R. Solomon, H. Shehu, N. Kamai, and L. Omoigui, "Maize-soybean intercropping for sustainable intensification of cereal-legume cropping systems in northern Nigeria," Experimental Agriculture, vol. 55, no. 1, pp. 73-87, 2019.

[38] F. Dereje, "The effect of variety and seed proportions on yield, nutritional quality and compatibility of oats and vetch mixtures," Doctoral dissertation, Addis Ababa University, Addis Ababa, Ethiopia, 2016.

[39] N. Rakeih, H. Kayya, A. Larbi, and N. Habib, "Forage yield and competition indices of triticale and barley mixed intercropping with common vetch and grasspea in the mediterranean region," Jordan Journal of Agricultural Sciences, vol. 6, no. 2, 2010. 